\title{
Popper's Politics and Law in the Light of African Values
}

\section{Thaddeus Metz ${ }^{1}$ (I)}

Published online: 15 June 2020

(C) Springer Nature Switzerland AG 2020

\begin{abstract}
Karl Popper is famous for favouring an open society, one in which the individual is treated as an end in himself and social arrangements are subjected to critical evaluation, which he defends largely by appeal to a Kantian ethics of respecting the dignity of rational beings. In this essay, I consider for the first time what the implications of a characteristically African ethics, instead prescribing respect for our capacity to relate communally, are for how the state should operate in an open society. I argue that while an Afro-communal moral foundation does not prescribe a closed society, it supports an open society politics and law of a sort different from the ones that Popper specifies. For Popper, the state in an open society should improve social arrangements albeit without seeking to promote a particular conception of the good life, should protect rights that merely serve the function of facilitating individual choice, and should employ majoritarian democracy to be able to avoid unwelcome rulers and policies. On all three counts, I show that a relational ethics typical of the African philosophical tradition entails different, intuitively attractive approaches to politics and law.
\end{abstract}

Keywords African morality · Communal relationship · Democracy · Individualism · Justice · Karl Popper $\cdot$ Liberalism $\cdot$ Open society $\cdot$ Relational values $\cdot$ Sub-Saharan ethics

\section{Introducing Popper in Relation to Africa}

Karl Popper did not say much about Africa, by which I mean the cultures salient among the black people indigenous to the continent, especially the Sub-Saharan part of it. Focusing on Popper's works in political and legal philosophy, they are plainly internal to the Western tradition. In terms of figures, Popper provides analyses of Plato's views of justice in the light of Greek society at the time, Immanuel Kant's conception of the enlightenment and its implications for how institutions ought to be structured, and Karl Marx's critique of capitalism and

Thaddeus Metz

tmetz@uj.ac.za

1 Department of Philosophy, University of Johannesburg APK, B-706, POB 524, Auckland Park, Johannesburg 2006, South Africa 
how it has been received by others. Regarding themes, Popper has considered how best to understand the nature of values such as freedom, democracy, and equality as characteristically understood in the West.

About the only thing in Popper's political and legal philosophy that suggests a bearing on Africa is his discussion of a closed society, where it is likely that he would have considered indigenous Sub-Saharan peoples to be instances of such. Although Popper's focus was Europe and he did not systematically engage in comparative intellectual history or philosophy, he clearly believes that Greek society alone spawned the values essential for an open society. For just one example, Popper remarks, 'The war of ideas is a Greek invention. It is one of the most important inventions ever made. Indeed, the possibility of fighting with words instead of fighting with swords is the very basis of our civilization'. ${ }^{1}$ The stereotype of traditional African cultures, particularly among mid-twentieth century western intellectuals, has been that they are both tribal and collectivist, which are the defining features of a closed society. That is, traditional African cultures have often been thought to place traditional beliefs and practices above question (tribalism) and to deem the clan to be morally more important than any given member of it, let alone strangers (collectivism). Indeed, it is not just stereotyping Westerners who have described indigenous Sub-Saharan peoples in these two ways, ${ }^{2}$ both of which Popper thinks run roughshod over individual rational reflection and choice, which, with Immanuel Kant, he considers to have the highest intrinsic value (beyond their instrumental use for social improvement).

One interesting project would be to question the degree to which pre-colonial African cultures were closed. For instance, one could cast doubt on this supposition by exploring the ideas that they tended not only to believe in human dignity, ${ }^{3}$ but also to resolve disputes by appeal to consensus consequent to deliberation, either among elders or, often enough, everyone with a stake in the outcome (under the proverbial tree). ${ }^{4}$

However, that is not my project here, which would be more apt for the historian or sociologist than for a philosopher. Instead, my aim is to draw on values salient in the African philosophical tradition in order to appraise several key elements of Popper's account of how the state should function in an open society. In particular, I appeal to the ideal of communal relationship that is prominent among African philosophers and their people in order to contest some of Popper's views. Specifically, after showing that Popper believes that the state in an open society should improve social arrangements albeit without seeking to promote a particular conception of the good life, should protect rights that merely serve the function of facilitating individual choice, and should employ majoritarian democracy to be able to avoid unwelcome rulers and policies, I argue that the relational value of communion grounds attractive alternatives.

Popper famously contrasts his individualism with collectivism. If the only choice were between contending that the individual person is most important and that the group is most important, I would argue in favour of individualism, including Popper's broadly Kantian version of it. However, this is a false dichotomy, in the sense that a third alternative is available. After Popper's central works in political and legal philosophy were published between the 1940s and the 1980s, a relational approach emerged in the English-speaking philosophical literature. Examples include the African philosophy of ubuntu (the southern

\footnotetext{
${ }^{1}$ Popper (1992), 373; see also Popper (1945a), 153.

${ }^{2}$ Cf. Ake (1987); Sogolo (1993), 121-129; Adeyinka and Ndwapi (2002), 18-19.

3 E.g. Gyekye (2010), sec. 6.

${ }^{4}$ E.g. Bujo (2009).
} 
African Nguni term for humanness), the Western feminist ethics of care, and the East Asian Confucian tradition. ${ }^{5}$ It is a certain interpretation of the African approach that I invoke here to cast doubt on Popper's politics and law. Although one scholar sees 'social' or 'communitarian' elements in Popper's views, ${ }^{6}$ I point out that they are weak, mainly in that Popper's appeal to relationality accords it value merely as a means. Given a plausible Afro-communal ethics, certain kinds of intersubjectivity should also be pursued as ends.

In the rest of this essay, I begin by sketching the aspects of Popper's political and legal philosophy that I will evaluate, after which I present the Afro-communal moral principle that I will use to do so. According to this ethics, ${ }^{7}$ an agent, including a state, ${ }^{8}$ has a basic duty to treat people as having a dignity in virtue of their ability to relate communally, described in some detail below. If what is special about people is their capacity for relationality and not so much their capacity for rationality as per Popper, then one arrives at different and plausible views of whether the state should be neutral in respect of the good life, which liberties it should protect, and how political power should be allocated within it. I conclude by briefly discussing some of Popper's other philosophical views that should be considered elsewhere.

\section{A Sketch of Popper's Politics and Law}

As is well-known and was mentioned in Section 1, Popper's political and legal philosophy is centred on a distinction between open and closed societies. In this section, I expound Popper's ideal of an open society and his underlying motivation for it (Section 2.1), after which I spell out the political and legal principles he believes are appropriate for it (Section 2.2). I evaluate these principles only in the following sections.

\subsection{The Open Society and Its Ethics}

By an 'open', as opposed to 'closed', society, Popper has in mind two major features, at least in The Open Society and Its Enemies. ${ }^{9}$ First, there is what he calls the 'intellectualist distinction', ${ }^{10}$ concerning the degree to which people evaluate and change social arrangements according to their reasoned judgement. For example, Popper remarks that an open society is one that 'sets free the critical powers of man'11 or that 'the open society is one in which men have learned to be to some extent critical of taboos and to base decisions on the authority of their own intelligence'. ${ }^{12}$

A society is closed, then, insofar as some facets of it are beyond question and may not be subjected to criticism by its members. ${ }^{13}$ Perhaps some social rules are deemed to be the will of

\footnotetext{
${ }^{5}$ Surveyed in Metz and Miller (2016).

${ }^{6}$ Afisi (2016a, 2016b).

${ }^{7}$ First articulated and defended in Metz (2011a, 2012a).

${ }^{8}$ Or its officials, if one denies that a state can be an agent.

${ }^{9}$ The phrasing is somewhat different in a later essay; see Popper (1976a), 78.

${ }^{10}$ Popper (1945a), 178.

${ }^{11}$ Ibid., 1.

12 Ibid., 178.

13 This distinction is reminiscent of Jürgen Habermas' $(1984,1987)$ distinction between modern and pre-modern societies, where the former are characterised by rationalisation processes, one major form of which is the increased extent to which society (or at least the lifeworld dimension of it) is determined by communicative action.
} 
God or of the clan's ancestors, or maybe some of them have been laid down by an elite group of human persons who think they know better than anyone else by virtue of, say, divine revelation, social class, or educational background.

Second, there is a distinction in terms of value, with Popper saying that the 'collectivist society will also be called the closed society, and the society in which individuals are confronted with personal decisions, the open society'. ${ }^{14}$ Elaborating, Popper says, 'I use the term 'collectivism' only for a doctrine which emphasizes the significance of some collective or group, for instance, 'the state' (or a certain state; or a nation; or a class) as against that of the individual', ${ }^{15}$ and he speaks of the closed society's 'creed that the tribe is everything and the individual nothing'. ${ }^{16}$

Whereas a closed society accords a normative priority to a group over its members and other individuals beyond it, an open one instead adheres to individualism, the 'belief in the human individual as an end in himself'. ${ }^{17}$ So construed, individualism is not equivalent to egoism, and instead is the idea that other people besides a given agent can matter for their own sake apart from their being members of a group. Part of treating other people as ends in themselves, and not merely as a means, is giving them the responsibility to make decisions as well as holding people accountable for their decisions.

These two distinctions, regarding the extent to which society is rationally evaluated and the degree to which individuals are respected, are different from one another. However, for Popper there is a close conceptual relationship between them, given a Kantian understanding of what precisely it is about the individual that merits respect, viz., her capacity for rational reflection and free choice. If each individual is special because he is 'born with the burden of responsibility for free decision', ${ }^{18}$ or if 'the dignity of man lies in his freedom', ${ }^{19}$ then respect for individuals means allowing them to exercise their intellectual powers and to act on their deliverances, i.e. to rationally evaluate the society in which they live and to change it on that basis. Indeed, at one point, Popper characterises an open society as 'a way of living together, based upon the idea of not merely tolerating a man and his convictions but of respecting him and his convictions'. ${ }^{20}$ When, in contrast, a group proclaims itself uniquely qualified to decide on certain matters, which are treated as taboo, it fails to treat others with equal respect in virtue of their ability to choose freely according to their own deliberation.

Hence, there is an ethical foundation for Popper's political and legal philosophy, namely, a broadly Kantian account of what is valuable about human nature as distinct from animal nature:

Beginning with the suppression of reason and truth, we must end with the most brutal and violent destruction of all that is human....We can return to the beasts. But if we wish to remain human, then there is only one way, the way into the open society. We must go on into the unknown, courageously, using what reason we have. ${ }^{21}$

\footnotetext{
${ }^{14}$ Popper (1945a), 152.

15 Ibid., 179

${ }^{16}$ Ibid., 166.

17 Ibid.

${ }^{18}$ Popper (1994a), 134.

${ }^{19}$ Popper (1994b), 138; see also Popper (1976b), 100.

${ }^{20}$ Popper (2008a), 236.

${ }^{21}$ Popper (1945a), 177. I thus disagree with one commentator who believes that what Popper "needs is some positive account of human nature, which will enable us to see the value of critical rationalism as an expression of that nature over its competitor faiths. But it is just this that he fails to offer' (O'Hear 2004, p. 194). I believe Popper does offer such an account (even if there are strands of his thinking that prevent him from maintaining that it is epistemically justified relative to competitors).
} 
What is human, for Popper, is our capacity to reason, limited as it is, while what is beastly or animal is not grounded on that, and is instead emotional, mythical, mystical, or religious. Morality, then, is fundamentally a matter of equal respect for that higher, distinctively human capacity for critical reflection. As Popper remarks, '(T)he only attitude which I can consider to be morally right is one which recognizes that we owe it to other men to treat them and ourselves as rational', ${ }^{22}$ and 'I maintain, with Kant, that it must be the principle of all morality that no man should consider himself more valuable than any other person'. ${ }^{23}$

\subsection{The Open Society and Its Politics and Law}

Having spelled out what an open society is and why Popper morally prefers it to a closed one, what remains to discuss in this section is what an open society would concretely look like in terms of its political and legal institutions. On this score, I consider three facets of how Popper believes that a state in an open society must treat those in its territory.

First, when it comes to what the function of the state should be, Popper contends that the state should serve a strictly 'protectionist' function, ${ }^{24}$ which for him means that its final end should be to prevent people's freedom from being undermined, especially those who are in a weaker position of power.

I demand protection for my own freedom and for other people's. I do not wish to live at the mercy of anybody who has the larger fists or the bigger guns....(T)he fundamental purpose of the state should not be lost sight of; I mean the protection of that freedom which does not harm other citizens. Thus I demand that the state must limit the freedom of the citizens as equally as possible, and not beyond necessity. ${ }^{25}$

If liberalism is the doctrine that the point of the state is to protect people's abilities (and especially their equal liberties) to act in ways they see fit, then Popper is a liberal, and he often describes himself as such. ${ }^{26}$

Some have read these and similar remarks from Popper as indicating that he is not merely a liberal, but also a libertarian, according to which the only proper job of the state is to prevent harmful interference, such that it would be unjust to tax the rich so as to fund access to education and to relieve poverty. While there are some passages that could be read in that way, ${ }^{27}$ there are others, ranging over more than 30 years, that simply cannot. Indeed, Popper explicitly says, as early as The Open Society and Its Enemies, that his protectionist doctrine rules out libertarianism:

We must construct social institutions, enforced by the power of the state, for the protection of the economically weak from the economically strong. The state must see to it that nobody need enter into an inequitable arrangement out of fear of starvation, or

\footnotetext{
22 Popper (1945b), 227.

${ }^{23}$ Popper (1945a), 219. For a different reading of Popper's foundational ethics, focused on the negative golden rule, see Pralong (1999), 136-138. Popper is also sometimes read as advancing negative utilitarianism, but Popper explicitly disavows it as a moral criterion (instead advancing it as a rough guide to public policy); see section 13 of the Addenda to Volume II of the fifth edition of the Open Society and Its Enemies (Popper 1966).

${ }^{24}$ Popper (1945a), 96-100.

25 Ibid., 96.

${ }^{26}$ E.g. Popper (1992), 8, 6-7, 351, 374.

${ }^{27}$ For one who appears to accept a libertarian reading of Popper, see Corvi (1997), 72.
} 
economic ruin....(I)f we wish freedom to be safeguarded, then we must demand that the policy of unlimited economic freedom be replaced by the planned economic intervention by the state. ${ }^{28}$

Enough said. $^{29}$

Although Popper favours regulating and taxing market exchanges in order to protect the poor from being dominated, including by funding their higher education, ${ }^{30}$ he is against paternalism and moralism, the views that the state should strive to promote well-being or virtue in people's lives, respectively. Instead, Popper approvingly points out how during his lifetime in the West there was

between the laws of the state, on the one hand, and on the other the taboos we habitually observe, an ever-widening field of personal decisions....We make rational decisions....We recognize rational personal responsibility'. ${ }^{31}$

Popper deems it a Platonic, and hence objectionable, view that 'the state should look after the moral life of its citizens'. ${ }^{32}$ One familiar contemporary way of putting this point is that the state must be 'neutral' in respect of conceptions of a happy, virtuous, and more generally good life. Instead of punishing people for not being better people or manipulating them so that they will be better off, the state should refrain from making judgements of these matters, letting citizens decide for themselves how to live their lives and bear the consequences (presumably including being held accountable for reducing the freedom of others).

Note how Popper's foundational ethics, of respect for rational decision-making, plausibly justifies the combination of accepting redistributivism while rejecting paternalism/moralism, or of what is sometimes described as state interference in the boardroom but not in the bedroom. Popper suggests that a principle of protecting freedom, understood as the ability to make one's own reasoned choices, means that the state must provide wealth to those who lack it for no fault of their own, so that people are able to choose from a variety of ways of life, but may not overrule people's own reflective choices when it comes to how to live their lives. Popper has hence predated by more than two decades other influential Kantian liberals such as John Rawls and Ronald Dworkin.

A second political-legal dimension of an open society concerns the sorts of rights that the state in it would protect. In a word, given Popper's individualism, they would all be equal human rights, that is, rights the bearers of which are individual persons. ${ }^{33}$ Such a restriction means that no group, such as a people, has rights that the state should enforce. Indeed, Popper explicitly rejects the idea of an 'alleged right of a nation to self-determination', calling it an 'absurdity', ${ }^{34}$ with one commentator saying, 'Popper's indictment of nationalism is wholesale'. ${ }^{35}$ Furthermore, if what confers a dignity on us is our capacity for reason, it follows that

\footnotetext{
28 Popper (1945b), 117.

${ }^{29}$ However, for those wanting additional redistributivist passages, see Popper (1945a), 97, 115; (1945b), 118;

(1976a), 78, 83. For a similar reading, see Shearmur (1996), 112-114.

${ }^{30}$ Popper (1945a), 115.

31 Ibid., 152.

32 Ibid., 114; see also 99 and Popper (1945b), 29.

${ }_{33}$ Popper (1945a), 77; (1976b), 100; (1992), 5, 363.

${ }^{34}$ Popper (1992), 367-368.

${ }^{35}$ Vincent (2005), 38.
} 
those humans that are not persons, i.e. that lack the power to reason, do not have human rights either (although they might be entitled to other protections, e.g. as beings who can suffer).

In addition, given Popper's rationalism, the content of the rights consists of what would particularly serve the function of enabling individuals to develop, exercise, and act in accordance with their critical faculties. '(E)very man should be given the right to arrange his life himself so far as this is compatible with the equal rights of others' ${ }^{36}$ Concretely, this principle means rights to information, scientific enquiry, academic freedom, speech, a free press, religious freedom, association, and the like all merit enforcement. ${ }^{37}$ The idea that the state should protect only such open-ended liberties, ones enabling people to pursue a wide array of forms of life of their choosing, contrasts with, for instance, the view that the state should enable people to live objectively well.

A third major feature of a state in an open society for Popper is a democratic distribution of political power or, more carefully, of the ability to remove rulers. Popper maintains that it would be unjust to restrict political choice to a particular group with a purportedly special knowledge. Neither divine revelation nor educational attainment nor virtuous character is a proper ground for being able to lay down the law or choose those who will. '(T)he Platonic idea of the rule of the wise and good should, I believe, be rejected unconditionally' ${ }^{38}$ Instead, those who rule must be able to be democratically replaced, supposing 'we mean by 'democracy' the control of the government by majority vote'. ${ }^{39}$

Popper's justification for democracy is not the following one that not only is so familiar, but also fits so well with his dignity-based morality and conception of an open society. This is the rationale that since all persons have a dignity in virtue of their capacity to reason, and since everything about social interaction should be subjected to rational criticism, a state must afford everyone the opportunity to choose the content of the law for themselves or in principle be allowed to provide critical input. Allocating every person an equal vote in order to give them an equal voice appears to follow straightaway from both of the two defining features of an open society, viz., individualism and rationalism. However, this is not Popper's reasoning, insofar as it suggests the importance of self-governance for democracy. Popper rejects a conception of democracy as rule by the people, and instead puts his point by saying that a state must 'enable its citizens in practice to change a government without bloodshed when a majority wishes such a change'. ${ }^{40}$ Instead of violence being necessary to change a state's rulers or rules, such change should be made on the basis of free choice. Popper calls this a 'theory of majority power of dismissal' ${ }^{41}$ and says that it was the "most important point' ${ }^{42}$ of his magnum opus, The Open Society and Its Enemies. ${ }^{43}$

Although Popper most often considers the question of how to replace rulers, he also at times addresses, at least implicitly, the further questions of how much power rulers should have relative to others and how they ought to exercise it when picking the rules. For example, Popper rejects a parliamentary, proportional representation system of government in favour of a two-party system, for a variety of reasons. First, there is the idea that when there is a clear

\footnotetext{
${ }^{36}$ Popper (1992), 363.

${ }^{37}$ Popper (1945a), 115, 171; (1945b), 214, 225; (1976a), 78-79; (1992), 347-354.

${ }^{38}$ Popper (1994c), 221.

${ }^{39}$ Popper (2008a), 243.

${ }^{40}$ Popper (1999a), 89; see also (1976a), 85; (1992), 350; (1994c), 220; (1999b), 96-97; (2008a), $242-243$.

${ }^{41}$ Popper (1999b), 97.

42 Ibid., 93.

${ }^{43}$ See Popper (1945a), 106-111; (1945b), 119, 140-141, 149-150.
} 
'majority government', 44 it can more easily be held accountable and threatened with removal by another party waiting in the wings to govern. 'Proportional representation creates the danger that the majority verdict at the polls, and hence the effect of defeat upon parties that is beneficial to democracy, will be regarded as a trivial detail'. ${ }^{45}$ Second, Popper points out that in a system of proportional representation, parties, not persons, are what citizens vote for, and then those who hold office do so as representatives of the parties that have appointed them, not of citizens. ${ }^{46}$ Popper prefers a system in which members of a legislature represent citizens directly, even if they are affiliated with parties. Third, Popper notes that in a system of proportional representation, 'small parties can exercise a disproportionately great - and often decisive - influence, both on the formation of a government and on its resignation, and so on all its decisions'. ${ }^{47}$

Popper's alternative to a proportional representation system is a two-party system, characteristic of the USA. Here, the governing party has defeated the other by having received the majority of votes from citizens in a winner-take-all apportioning of them. And when deciding which laws to adopt, the elected representatives seek to advance the interests of their respective constituencies by marshalling enough votes to obtain a majority in the legislature.

In the rest of this essay, I do not question Popper's preference for an open society, that is, one characterised by individualism and rationalism, but do provide reason to doubt that his political prescriptions are uniquely apt for such a society. Upon advancing a moral foundation different from Popper's, I show that an alternative politics grounded on it could be appropriate for an open society and is prima face attractive.

\section{An Afro-Communal Ethics}

In this section, I advance a moral principle intended to rival Popper's Kantian one of treating persons as rational. In a broad sense, both his principle and mine are individualist, in that both ethics imply that something other than groups are morally most important, and specifically, that it is a human person that has a dignity. However, in a narrow sense, my principle is an alternative to Popper's form of individualism, which is Kantian (even if not specifically Kant's).

For Popper, the individual has a dignity in virtue of her intrinsic properties, features of hers that make no essential reference to anyone else, namely, her 'convictions', as above. To be sure, the ability to act on rationally acquired beliefs, as opposed to operate on instinct or conditioning, is to be exercised in a social manner for Popper, e.g. in the forms of scientific enquiry and democratic polity. However, his Kantian foundation influences the nature of sociality that is justified relative to a different, more fundamentally relational ethics. Or so I argue in the following section, after in this section drawing on the African philosophical tradition to propose a relational ethics according to which what makes a person morally important is her ability to relate communally with others. ${ }^{48}$

\footnotetext{
${ }^{44}$ Popper (2008b), 368.

${ }^{45}$ Popper (1999b), 97; see also (2008b), 367-369.

${ }^{46}$ Popper (2008b), 365-367.

47 Ibid., 367-368.

48 The following paragraphs were borrowed from Metz (2015a, 2017); what is intended to be new in this article is not the African ethics, but rather its application to political philosophical issues in ways that provide powerful alternatives to Popper's views. For different approaches to Sub-Saharan morality, see, for just two examples, Bujo (2005), who takes vital force to be a basic value to be promoted, and Gyekye (2010), who treats the common good as foundational.
} 
Instead of conceiving of morally right action in terms of what respects a final good intrinsic to a person, such as her capacity for rationality (or her autonomy, life, or being an organism), my favoured ethics places a certain way of relating between individuals at the ground of how to treat others. The claim is not that relationships matter and individuals do not, but instead that individuals matter because they are capable of certain relationships.

As noted above, the word 'ubuntu' means humanness in some of the indigenous languages of southern Africa, and it is widely used to capture the morally salient features of Sub-Saharan philosophies. According to this morality, one is at bottom to exhibit ubuntu, that is, to live a genuinely human way of life. Those who fail to do so are often called 'non-persons' or even 'animals', ${ }^{49}$ metaphorical terms suggesting that people have failed to realise what is special about their human nature.

Like Popper, then, a large swathe of indigenous African morality distinguishes between human and animal nature, and prescribes becoming more human and eschewing becoming like a beast. However, they differ in terms of what it is about human nature that is highly valuable for its own sake. Whereas for Popper, it is our capacity for rationality, a more African view is that it is our capacity for relationality. An influential maxim associated with ubuntu is 'A person is a person through other persons', which, morally understood, prescribes developing into a real person or genuine human being, something one can do by relating positively to others in certain ways. ${ }^{50}$

The following comments by scholars of African ethics, from places as diverse as Uganda, South Africa, Zimbabwe, and Kenya, suggest some kind of relational approach to morality:

(I)n African societies, immorality is the word or deed which undermines fellowship. ${ }^{51}$ When we want to give high praise to someone we say, 'Yu, u nobuntu'; 'Hey, he or she has ubuntu.' This means they are generous, hospitable, friendly, caring and compassionate.... Social harmony is for us (Africans - ed.) the summum bonum - the greatest good. Anything that subverts or undermines this sought-after good is to be avoided like the plague. ${ }^{52}$

(O)ne should always live and behave in a way that maximises harmonious existence at present as well as in the future. ${ }^{53}$

A life of cohesion, or positive integration with others, becomes a goal, one that people design modalities for achieving. Let us call this goal communalism, or, as other people have called it, communitarianism. In light of this goal, the virtues.....become desirable. ${ }^{54}$

I do not take these comments about fellowship, harmony, and communalism at face value, for doing so has counterintuitive implications regarding human rights, which my principle is meant to capture (argued below). As they stand, they variously suggest that certain (harmonious or communal) relationships are good for their own sake, that it is always wrong to undermine them, and that one should promote them as much as possible. However, if existing relationships alone were ethically relevant, then a person not in the relevant relationship with an agent, such as a stranger in a foreign land, would lack moral standing relative to her. If it was always wrong to act in ways that undermine the relevant relationship, then threats, violence, and other forms of force would be categorically

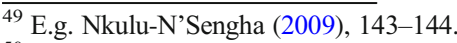

${ }^{50}$ For just two sources, see Khoza (1994) and Mokgoro (1998), 17.

${ }^{51}$ Kasenene (1998), 21.

52 Tutu (1999), 35.

${ }^{53}$ Murove (2007), 181.

${ }^{54}$ Masolo (2010), 240. 
impermissible, even when directed against aggressors in order to protect innocents. Moreover, if one were supposed to maximise the relevant relationships, then it would be permissible to use any means whatsoever, including intentionally harming innocents in severe ways, whenever doing so would promote harmony in the long run.

To avoid these implications while retaining a relational approach, I advance a principle according to which individuals have a dignity in virtue of their communal nature, or capacity for harmony, that demands respect. The idea is not that being part of a particular community confers a dignity that must be recognised by members of it, but rather than being able to relate communally with anyone must be recognised by anyone.

By 'communion' or 'harmony' I mean the combination of two logically distinct relationships that are often implicit in African characterisations of how to live well. ${ }^{55}$ Consider these quotations from an additional group of philosophers, theologians, and related theorists from Nigeria, Ghana, and South Africa:

Every member is expected to consider him/herself an integral part of the whole and to play an appropriate role towards achieving the good of all. ${ }^{56}$

$(\mathrm{H})$ armony is achieved through close and sympathetic social relations within the group. $^{57}$

The fundamental meaning of community is the sharing of an overall way of life, inspired by the notion of the common good. ${ }^{58}$

(T)he purpose of our life is community-service and community-belongingness. ${ }^{59}$

Notice that, in these characterizations of how to commune or harmonize, two logically distinct relationships are repeatedly mentioned. First, there is considering oneself part of the whole, being close, sharing a way of life, and belonging, which I label 'identifying with' or 'sharing a way of life with' others. Second, there is achieving the good of all, being sympathetic, acting for the common good, and serving the community, labelled 'exhibiting solidarity with' or 'caring for' others. Note how these are different ways of relating: one could cooperate with others on projects that are not good for them, and, conversely, one could act in ways that are good for others but do not include participating with them even-handedly.

For the purposes of this essay, it will be enough to work with the following representation of communion or harmony (Fig. 1).

By the ethics advanced here, it is not this communal relationship that has a basic moral value, but rather an individual's natural capacity for it. Typical human beings, for example, have a dignity insofar as they are in principle able both to be communed with and to commune. The highest moral status accrues to human persons generally, beings that by nature can be both objects of a harmonious relationship, viz., able to be identified with and cared for by others, and subjects of it, able to identify with and care for others.

There are two key differences between this account of dignity and Popper's. Although all cooperation involves the exercise of reasoned decision-making, not all exercise of reasoned decision-making involves cooperation. Popper's account entails that a psychopath, by which I

\footnotetext{
$\overline{55}$ Initially distinguished and reconstructed in Metz (2007).

${ }^{56}$ Gbadegesin (1991), 65.

${ }^{57}$ Mokgoro (1998), 17.

${ }^{58}$ Gyekye (2004), 16.

${ }^{59}$ Iroegbu (2005), 442.
} 


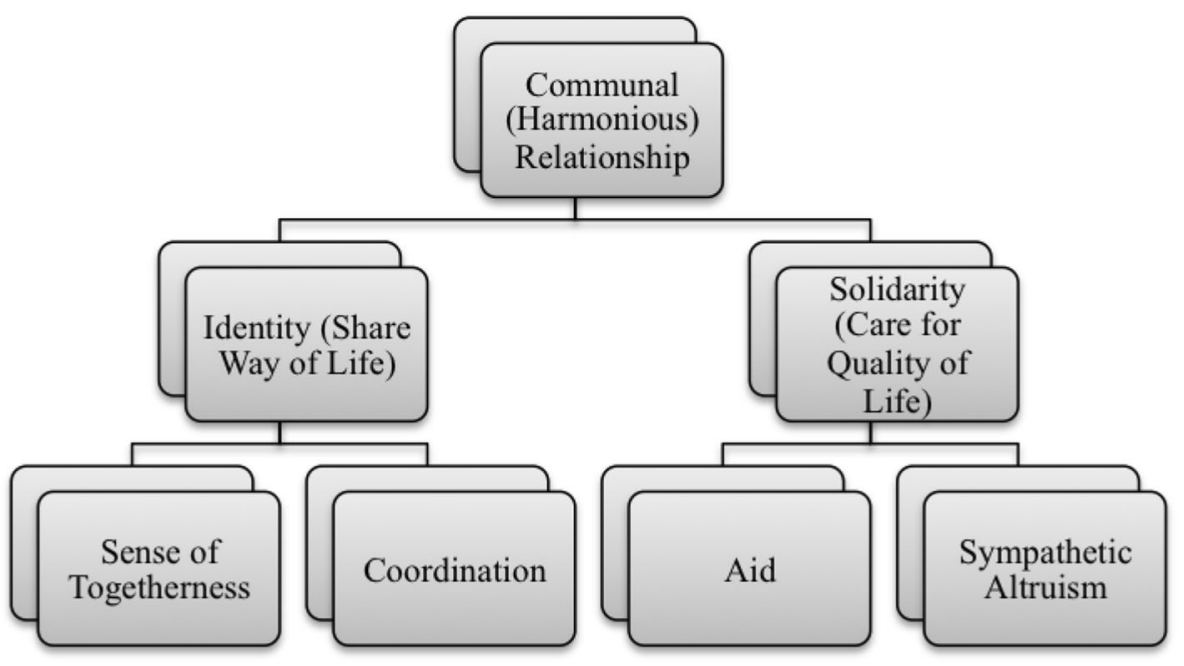

Fig. 1 Schematic representation of harmony

mean someone substantially incapable of other-regard, could have a dignity equal to ours (even if his behaviour would be liable to criticism), but the Afro-communal account entails that such an individual does not (but could still warrant certain kinds of moral treatment for its own sake). ${ }^{60}$ In addition, for Popper, it is strictly our agency that confers a dignity on us, whereas, by the Afro-communal account, it is that specifically qua other-regarding plus our patiency, i.e. our capacity for others to identify with and exhibit solidarity toward us. In a nutshell, by the African account, it is our ability both to love and be loved in a broad sense that makes a given one of us the most important beings, morally speaking, on the planet.

Turning from moral status to normative theory, I propose that an act is right insofar as it respects others in virtue of their natural capacity to relate communally or harmoniously; otherwise, an act is wrong. Equivalently, an act is wrong if and only if degrades others who can in principle be party to relationships of identity and solidarity, especially insofar as (roughly) it treats innocent parties in extremely anti-social or discordant ways, with enmity. Discord consists of the opposites of identity and solidarity, where instead of togetherness and coordination, there is distance and subordination (together constituting division), and instead of altruism and aid, there is cruelty and harm (ill-will) (Fig. 2).

From this perspective, what typically makes actions such as lying, promise breaking, abusing, kidnapping, and the like immoral is that they treat innocent parties discordantly and thereby disrespect their capacity to be harmonised with and to harmonise. ${ }^{61}$

That explanation of why these acts are wrong is, I submit, prima facie plausible and differs from the Kantian notion that acts are wrong because they are degradations of rationality or free choice. Instead, wrong acts by the present ethics are those failing to treat people as special in virtue of their capacity for harmonious relationships. If a person has not been discordant, then there is strong reason to treat her in a harmonious manner, roughly, to coordinate with her and do what it is expected to benefit her. Typically then, indifference and isolation are immoral,

\footnotetext{
${ }^{60}$ For further discussion, see Metz (2012b), 397-398.

${ }^{61}$ Although markets and bureaucracy fail to exemplify some harmony, as conceived of here, they do not essentially involve discord either. For brief discussion of how the present ethics bears on these modern institutions, see Metz (2014a), 68-70.
} 


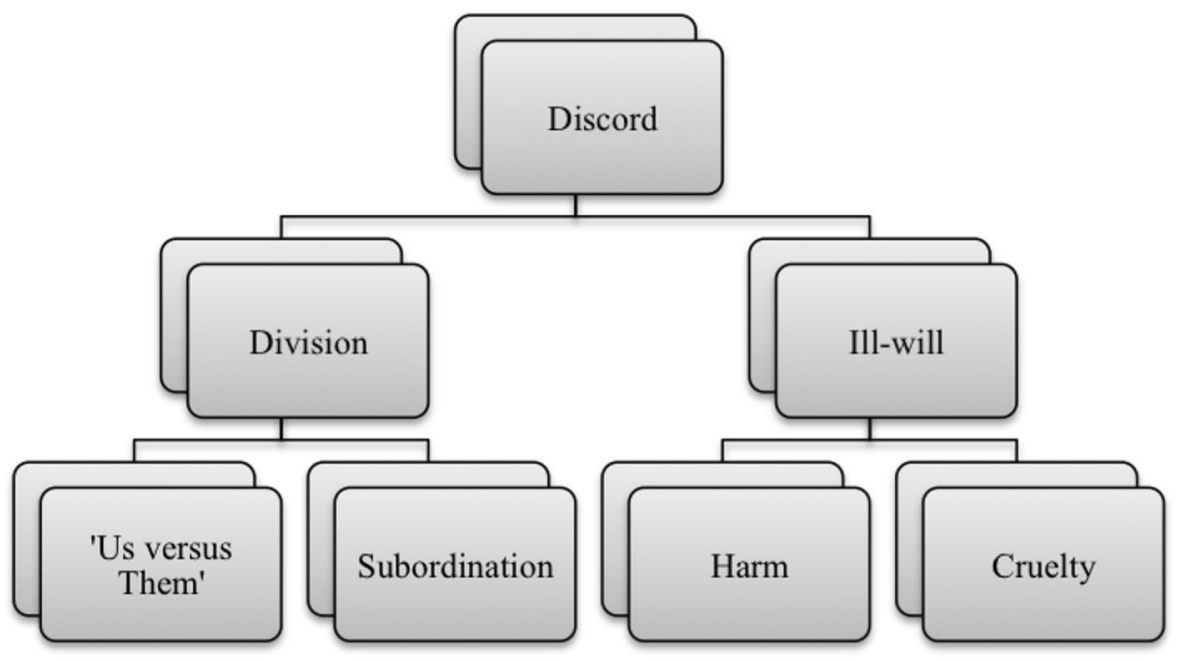

Fig. 2 Schematic representation of discord

and worse are discordant actions involving subordination consistent with an 'us versus them' attitude as well as harm consistent with a selfish motivation.

However, it does not follow that discordant actions are always wrong. They are instead wrong when, and only when, they fail to express respect for the dignity of people's communal nature, which they need not do. It is one thing to act discordantly toward someone who has not herself acted that way. If someone has not initially acted in a discordant way and has instead related harmoniously with others (who themselves have not been discordant, let us suppose), then she counts as 'innocent' and is liable for only harmonious treatment. Were one to treat an innocent person in a severely discordant way, most often one would be thereby violating her human rights, even if in the long run more harmony would be fostered in society. What killing, torture, slavery, rape, human trafficking, apartheid, and other gross infringements of civil liberties and equal opportunities arguably have in common is that they are instances of substantial discord directed to those who have not acted this way themselves, thereby denigrating their special capacity to be party to relationships of identity and solidarity.

This account of what constitutes a human rights violation plausibly rivals the Kantian rationale in terms of the degradation of reasoned decision-making. To be sure, subordination involves suppressing another's ability to make a reasoned decision for herself. However, by the present approach to human rights, it is not merely subordination that counts but also harm, the reduction of people's quality of life. That could be a matter of making people worse off, but it might also be a matter of making them worse people, i.e. impairing their capacity to relate communally with others, that is, their ubuntu. Inherent to the analysis of human rights violations in terms of discordance is a conception of the good (and bad), specifically of both well-being and excellence, where it is plausible to think that what constitutes a human rights violation, such as torture, is characteristically behaviour that makes others badly off, that harms them.

The differences between Popper's ethics and the African one entail divergent prescriptions about how state institutions ought to be structured. To the extent that one finds the African ethics attractive, that is some reason to favour its prescriptions. However, many readers will 
find the prescriptions prima facie plausible in themselves, even if they are not yet convinced of the specific moral principle from which I derive them in the following section.

\section{From the Afro-Communal Ethics to Politics and Law}

The three facets of Popper's political and legal philosophy that I have expounded are his views of neutrality, liberty, and authority (in catchwords). Given his Kantian moral foundation, Popper is (or at least believes himself to be) committed to the views that the state should not seek to advance particular conceptions of the good life, should instead protect only the abilities of individuals to live as they see fit, and should give a majority of citizens the final authority to pick (or replace) rulers and a majority of rulers the final authority to pick rules. In this section, I provide reason to doubt each of these views, arguing that Popper's politics and law are insufficiently communal.

I do not deny Popper's view that an open society is preferable to a closed one. In fact, treating people as having a dignity in virtue of their capacity to commune forbids both treating groups as having the highest final value and discouraging people from questioning social arrangements. After all, neither feature of a closed society is compatible with cooperative relationships between people, which is central to communion. However, it does not follow that Popper's specific conception of how the state ought to function in an open society is justified; what follows is another, arguably more appealing vision of what politics and law there could look like.

\subsection{The Good Life and Political Choice}

Recall, first, that, for Popper, the state ought to be neutral in respect of people's well-being or virtue, or in his words that 'the politician should limit himself to fighting against evils, instead of fighting for 'positive' or 'higher' values, such as happiness' ${ }^{62}$ According to Popper, the state should not make on any decision based on a judgement regarding which ways of life are better than others, and it should instead merely protect citizens' freedom to choose their preferred lifestyles. However, by the Afro-communal ethics, an agent is to treat others as important in virtue of their ability to commune and to be communed with, which, in turn, means relating to them in beneficent ways. According to this relational morality, for the state not to care about its citizens' happiness and moral life would be for it to fail to treat them with respect.

Such care need not take a coercive form, and usually should not, given the cooperative dimension of a communal relationship. A policy of enabling others to live better, and particularly more moral, lives need not be construed in terms of 'state-enforced norms'. ${ }^{63}$ Instead of punishing people for harming themselves or exhibiting vice, an Afro-communal state might facilitate and encourage other, more communion-friendly choices. ${ }^{64}$ For example, the state could fund couples counselling for the public, with the aim of strengthening marriages and other intense communal relationships. Similarly, it could offer parenting classes, in order to make it more likely that children flourish. It could also offer instruction on emotional

\footnotetext{
${ }^{62}$ Popper (1945b), 263.

${ }^{63}$ Popper (1945a), 99.

${ }^{64}$ First discussed in Metz (2011b), 238-239.
} 
intelligence and conflict resolution, to help co-workers and neighbours get along better. These sorts of courses would presumably be offered in a state clinic of some kind that would be associated with a department of social welfare, and on the face of it they could do a lot of good compared with their absence.

Consider, now, how a state university might operate to foster virtue among its students, which they would have been less likely to acquire without such public support. For Popper, higher education ought to be strictly devoted to fostering 'a critical appreciation of the things that are said (and the things that are done)'. ${ }^{65}$ However, part of honouring people's capacity to commune is enabling them to exercise it, meaning that a publicly funded university might also teach students, say, how to become more aware of their implicit biases, how to identify and deal with conflicts of interest, and how to become more attuned to other people's points of view and feelings. In addition, university pedagogy could incorporate what are often called 'communities of practice', where students would learn by collaborating with others to realise shared goals. Relationships of sharing a way of life and caring for others' quality of life are more likely to be realised in the context of joint public activities than isolated assignments done or prepared for at home in which students are competing against each other for grades. Still more, enabling students to excel at the right sort of job, meaning one that would contribute positively to others' good, would be a significant way for a university to impart virtue. If the state must treat people as having a dignity because of (in part) their capacities to be cared for and to care for others, then it must care for each of them by enabling them to find work in accordance with their particular abilities and inclinations to care for others. ${ }^{66}$

Similar kinds of approaches would be apt for other state-funded institutions, such as healthcare. It would be reasonable, for instance, to use public funds to treat psychopathy, autism, narcissism, and racism with an eye toward enabling people to become more communal (where that includes treating innocent strangers harmoniously). For another example, when the state fights poverty, it would not merely dole out money that could be used to obtain whatever end poor people might want, but instead would in the first instance provide resources that are objectively good for them, such as enabling them to access nature, neighbourhood parks, artistic productions such as plays and concerts, tools with which they could be creative, and of course education and healthcare.

I have argued that these kinds of virtue-friendly policies follow from an Afro-communal ethical foundation, but I presume that they have some intuitive pull even for those who do not share that value system. Note that these policies need not be placed above democratic deliberation, viewed as a function of superior knowledge that only a few have and that are rammed down citizens' throats. Instead, these policies may be offered as the conception of justice that an elected government ought to adopt for citizens, including for those with diverse religious and cultural backgrounds. In addition to avoiding tribalism, these policies are also not collectivist; they are in no way fundamentally oriented toward supporting a particular group such as a people or a state.

Popper would no doubt object that we cannot know what is objectively good for human beings, or at least that we might be mistaken about that. However, he has himself advanced not only a principle of morally right action, but also a conception of dignity on which it is grounded as well as companion accounts of how the state ought to function. If he can take

${ }^{65}$ Popper (1945b), 262; see also 263 and Popper (1945a), 115.

${ }^{66}$ Metz (2015b), 209-214. 
seriously those normative and evaluative principles in the face of either scepticism or fallibilism, then he can do the same for an Afro-communal approach.

\subsection{The Content of Legal Rights}

Let us turn to which kinds of rights a state ought to enforce on behalf of its citizens. The reader will remember that, according to Popper, the only bearer of rights should be an individual and that their content should involve enabling an individual to make a reasoned decision for herself. ' $(\mathrm{I}) \mathrm{t}$ is the end of the state to protect the freedom of its citizens' ${ }^{67}$ considered as individuals, and not, say, to enable national self-determination, where a nation could take the form of a community, meant here to signify systematic bonds of identity and solidarity. The Afro-communal ethics does entail that some broad individual freedom matters, insofar as cooperating is a central feature of relating communally. However, the ethics also prescribes protecting certain kinds of freedom more than others.

For example, above I noted the kind of freedom that the state would provide to its poorer citizens is not so much the ability to choose any way of life they want, but more the ability to choose ones that would be objectively good for them. Instead of going of its way to enable people to spread ugliness, ignorance, and hatred to a degree equal to beauty, knowledge, and love, an Afro-communal state would in principle provide the kinds of resources that are particularly conducive toward fostering well-being and virtue.

For another example, a state that treats its citizens with respect in virtue of their capacity to relate communally will protect a right to culture on their part. ${ }^{68}$ For an agent such as a state to treat people as special in virtue of their capacity for communal relationship, it must not degrade their particular, substantial actualizations of this capacity, viz., in the form of long-standing and widespread communities. Although a community qua instance of communion, understood as including a cooperatively shared a way of life (and so a kind of consent), is not one and the same thing as the mere capacity for such, it is people's exercise of that capacity. And it is plausible that respecting people's capacity for communion requires recognition of the way they have actualized it, or, equivalently, that degrading communal relationships is to degrade those individuals who have been party to them. So, if people have established communal relationships, then the state should respect them by not targeting them for destruction, by doing what it can to avoid impairing them, and by going out of its way to protect them, when the cost to other values is low.

These supportive activities could, first, include making exceptions to rules, permitting some collective self-determination over, say, civil matters. On this score, a state could enable different cultures to lay down what counts as getting married, subject roughly to the condition that both parties give their free and informed consent (and hence are relating harmoniously). A second way to enhance shared ways of life would be for the state to provide resources to support people's intellectual or aesthetic cultures. For instance, it could subsidise the publication of literature in different languages used within the state's territory, and of course it need not support only one language to the exclusion of others. A third way to protect communal identities might involve making privileges contingent on certain conditions so as to retard the encroachment of English. Consider Israel's policy of making a radio broadcast licence

\footnotetext{
${ }^{67}$ Popper (1945a), 82.

68 The next few paragraphs were borrowed from Metz (2014b), 142-144. For a commentator sympathetic to the point, albeit not on characteristically African normative grounds, see O'Hear (2004), 196-197.
} 
conditional on $50 \%$ of transmissions being in Hebrew, a language at the heart of most people's self-conceptions there.

These kinds of policies do not rise to the level of 'national self-determination'. However, they are not far off, in that they are designed to protect communities, understood as realisations of people's capacity for communal relationships. By this approach, people's ability to retain and even enrich their culture merits protection not for corporate reasons; it is not a group right that grounds duties not to interfere with people when it comes to what they eat or how they worship together. Instead, if ever an agent were intentionally to disrupt (or sometimes fail to support, when he could easily do so) communal relationships, including a shared sense of self and cooperative practices, it would thereby express disrespect of the individuals who have a dignity because of their ability to relate communally.

In addition, note that the claim is not that the effect of impairing communion would be detrimental to individuals. Instead, the position is that when a specific cooperative practice has been willingly adopted by a large number of people for a long span of time and is central to their self-conception, it plausibly has a moral significance that can be worth respecting as an instantiation of their special capacity to relate communally. Such a rationale is, I submit, a plausible rival to the influential Kantian suggestion that culture matters merely because it facilitates the autonomous choices of individuals. ${ }^{69}$

\subsection{The Distribution of Political Power}

Third, and finally, I now take up Popper's defence of democracy. He maintains that it is preferable to tyranny on the ground that it enables a majority to change a state's rulers without violence. 'There are in fact only two forms of state: those in which it is possible to get rid of a government without bloodshed, and those in which this is not possible....All that counts is whether the government can be removed without bloodshed' ${ }^{70}$

So stated, Popper's remark is too crude. If literally the only thing that mattered were the ability to remove a sitting government without violence or even force, then one could, say, use a 'pass the hat' method. That is, every citizen could write down her preferred candidates on a piece of paper, place them all into a hopper, and then have a piece pulled out at random, with the current rulers stepping down supposing their names were not on it. Indeed, one could just have a computer pick citizens at random to serve in the government, where officials step down in accordance with the results of the lottery. ${ }^{71}$ These procedures are not really democratic, or, if they are, they are not an attractive sort on the face of it, despite removing the government without bloodshed.

Although these procedures avoid a violent transfer of power and they are 'fair' in a sense, what is missing from them (for one thing) is the element of choosing consequent to rational discussion about the qualifications and proposals of the candidates. On this score, Popper does in fact have intellectual resources that can plausibly explain why such deliberation is important: it is necessary to respect us as rational beings. Consider his remarks that democracy 'makes possible the reform of institutions without using violence, and thereby the use of reason in the designing of new institutions, ${ }^{72}$ and that 'in an open society there is the

\footnotetext{
$\overline{69}$ Kymlicka (1989); Rawls (2001), 93-94.

${ }^{70}$ Popper (1999b), 94; see also Popper (1976a), 85.

${ }^{71}$ For an advocate of this approach, see Guerrero (2014).

72 Popper (1945a), 110.
} 
possibility of free discussion and that discussion has influence on politics' ${ }^{73}$ Appealing to reason and free discussion indicates that it is not merely force-free dismissal that counts; what also matters is the collective, rational evaluation of political institutions.

However, one need not appeal to the Kantian value of rationality in order to make sense of why changing a government should be done in the light of the free choice of citizens upon deliberation of the alternatives. By the Afro-communal ethics, this procedure is appropriate as a way of respecting citizens who are capable of being party to relationships of identity and solidarity. Identifying with others means enjoying a sense of togetherness with them and choosing on a cooperative basis, where the first is more likely to result from a democratic procedure and the second is, more strongly, constituted by it. Part of a sharing a way of life with others is sharing political power, by this approach. In addition, there is the familiar idea that, when it comes to solidarity or caring for others' quality of life, a government is more likely to do what is good for its citizens if they have substantial input into who is in charge of it.

In fact, considerations of communion entail, contra Popper, that the right sort of democratic procedure would avoid a two-party system or other form of majority rule, and instead require unanimous agreement, where feasible, say, at the parliamentary level. For example, Kwasi Wiredu has famously put forward a proposal for a 'non-party polity' in which legislators, who have been elected by a majority of the populace (such being practically necessary in urban environments), would not be affiliated with a particular constituency for the sake of which they would jockey for a majority of votes. ${ }^{74}$ Instead, they would propose policies that they think are good for the public as a whole, and would adopt only those that are the object of unanimous agreement among themselves.

As is common for African political philosophers to point out these days, consensus would not necessarily mean that everyone agrees to the same policy for the same reasons, which would be unrealistic to expect. Instead at the core, it would mean that no one has objections serious enough to stand in the way of a policy's adoption. The notion of agreement is one of agreeing to letting a law pass because it is good enough for all, not agreeing that it is the best from every perspective.

Respect for people in virtue of their communal nature means seeking such unanimous agreement wherever it is practical, for two reasons. First, when it comes to identity, consensus among legislators would produce a stronger sense of togetherness between themselves and between citizens, and would also constitute a more intense form of cooperation than would majority rule. Second, in terms of solidarity, everyone's interests are more likely to be satisfied to an adequate degree by a given policy if everyone must ratify it than if a mere majority must do so. In short, with a consensual approach, there would not be a minority left completely out in the cold, that is, feeling alienated, being unsupported in its aims, and faring badly.

Before concluding, I address the suggestion that Popper's politics is more relational than it might appear at first glance. One Popper scholar, Oseni Afisi, has labelled Popper's political philosophy 'liberal-communitarian', ${ }^{75}$ which might lead one to suspect that I have drawn too stark a contrast between Popper's Kantian individualism and my Afro-communalism. Afisi sees 'a communitarian impulse ${ }^{, 76}$ and 'social aspects ${ }^{77}$ in Popper's politics, insofar as Popper recognises that dialogue with others is required in order for us to reason well. Because he

\footnotetext{
73 Popper (1976a), 78.

${ }^{74}$ Wiredu (2000).

${ }^{75}$ Afisi (2016a, 2016b).

${ }^{76}$ Afisi (2016a), 2.

77 Afisi (2016b), 13.
} 
acknowledges that 'individuals cannot author their own values without engaging critically with others', ${ }^{78}$ and that 'critical reflection with others is necessary if individuals are to act freely in fulfilment of their self-determination', ${ }^{79}$ Afisi believes that Popper's form of liberalism includes an important 'social dimension' ${ }^{\prime 0}$ that is missing from other forms of liberalism.

Setting aside the issue of whether other liberals have failed to recognise the prerequisites for autonomy, I maintain that the sort of sociality Afisi finds in Popper's position is not the robust sort advanced in this essay. Afisi is discussing a kind of intersubjective engagement is that 'necessary' for self-determination only in an instrumental sense, that is, as a causal tool by which to bring about a distinct state of affairs of authorship of one's own values or selfdetermination. Basically, it is only by engaging in dialogue and debate with others that we can efficiently set, pursue, and obtain our respective goals as individuals. In contrast, the relationality I have championed here is to be sought as an end, not merely as a means to a further end of autonomy. I have suggested that what is important about us is our capacity to relate communally with others, which entails a variety of rich alternatives to Popper's politics. Specifically, if critical reflection with others were of merely instrumental value, then we could not justify — or at least not nearly as straightforwardly — the views (among others) that the state should work to improve its citizens' objective quality of life, protect their culture as a way of treating them with respect, and seek consensus in the distribution of political power among legislators. These are, I maintain, prima facie plausible alternatives to Popper's views, and they are most naturally grounded on an ethics that would have the state exhibit and promote communal relationships as ends (albeit as ways thereby to express respect for persons capable of them).

\section{Concluding Remarks}

In this essay, I have critically addressed the sort of political and legal philosophy that Karl Popper believes is the companion to an open society. I have not rejected the ideal of an open society; I agree that a society should be neither tribal nor collectivist, as Popper conceives of these. However, I have questioned whether the state in an open society should function in the ways Popper believes, to the extent that they follow from his foundational commitment to a Kantian ethics according to which we are human insofar as we are rational. ${ }^{81}$ Suggesting, with the indigenous African tradition, that we are instead human insofar as we are relational and specifically communal, I have sketched a different politics and law. Roughly, the state need not avoid advancing certain conceptions of the good life, should not merely protect individuals' ability to live as they see fit, and should not rest content with the majority rule that is typical of a two-party system. Instead, the state should do things such as enable citizens to develop their virtue, help them safeguard and enrich their culture, and require consensual agreement among at least elected representatives before a law is considered valid. These and other policies, I have argued, would express respect for people as capable of being communed with and of communing.

\footnotetext{
78 Afisi (2016a), 3.

${ }^{79}$ Ibid.

${ }^{80}$ Ibid., 2.

${ }^{81}$ Leaving open the possibility that there are additional rationales for his political views beyond his Kantian ethics.
} 
If I am correct that such policies follow from an Afro-communal ethics, and if one finds this ethics attractive, then one is committed to the policies. However, as I have pointed out at times, the policies are in themselves reasonable alternatives to Popper's politics for an open society. There is nothing in them that is either tribal or collectivist, and so at least for that reason should be taken seriously by those sympathetic to Popper's broad programme.

In closing, I acknowledge that I have not addressed Popper's entire political philosophy. For example, I have not considered his defence of equal opportunity, the notion that the educational and employment positions available to a person should not be determined by factors such as social caste or parental wealth. I have not addressed Popper's evaluation of capitalism, the issue of who should be legally allowed to own the means of production. In addition, I have not taken up his rejection of revolutionary upheaval in favour of piecemeal change. If the Afro-communal ethics has entailed some plausible conclusions about the proper functions of the state in this essay, then I submit that it would be worth extending its applications to these matters in other work.

Acknowledgements This essay has been improved as a result of oral feedback received at the Conference on Karl Popper, Knowledge and Politics in Contemporary Africa organised by the Lagos State University in Nigeria in 2018 and written comments from an anonymous referee.

\section{References}

Adeyinka A, Ndwapi G (2002) Education and morality in Africa. Pastor Care Educ 20(2):17-23

Afisi OT (2016a) Popper, liberal-communitarianism, beyond the politics of liberalism. Philosophia: E-Journal Philos Cult 11:1-18

Afisi OT (2016b) Towards exploring an enduring liberal-communitarianism in Karl Popper through his intellectual biography. J Philos Cult Relig 24:13-22

Ake C (1987) The African context of human rights. Afr Today 34(1-2):5-12

Bujo B (2005) Differentiations in African ethics. In: Schweiker W (ed) The Blackwell Companion to Religious Ethics. Blackwell, Malden, MA, pp 423-437

Bujo B (2009) Springboards for modern African constitutions and development in African cultural traditions. In: Murove MF (ed) African ethics: an anthology of comparative and applied ethics. University of KwaZuluNatal Press, Pietermaritzburg, pp 391-411

Corvi R (1997) An introduction to the thought of Karl Popper. Routledge, London

Gbadegesin S (1991) African philosophy. Peter Lang, New York

Guerrero A (2014) Against elections: the lottocratic alternative. Philos Public Aff 42(2):135-178

Gyekye K (2004) Beyond cultures: perceiving a common humanity. The Council for Research in Values and Philosophy, Washington, DC

Gyekye K (2010) African ethics. In: Zalta E (ed) The Stanford Encyclopedia of Philosophy. Available online: http://plato.stanford.edu/archives/fall2010/entries/african-ethics/. Accessed 19 May 2020

Habermas J (1984) The theory of communicative action, volume 1: reason and rationalisation of society. McCarthy T (trans). Beacon Press, Boston

Habermas J (1987) The theory of communicative action, volume 2: a critique of functionalist reason, McCarthy T (trans). Beacon Press, Boston

Iroegbu P (2005) Beginning, purpose and end of life. In: Iroegbu P, Echekwube A (eds) Kpim of morality ethics. Heinemann Educational Books, Ibadan, pp 440-445

Kasenene P (1998) Religious ethics in Africa. Fountain Publishers, Kampala

Khoza R (1994) Ubuntu, botho, vumunhu, vhuthu, African humanism. Ekhaya Promotions, Sandton

Kymlicka W (1989) Liberalism, community, and culture. Oxford University Press, New York

Masolo DA (2010) Self and community in a changing world. University of Indiana Press, Bloomington

Metz T (2007) Toward an African moral theory. J Polit Philos 15(3):321-341

Metz T (2011a) Ubuntu as a moral theory and human rights in South Africa. Afr Hum Rights Law J 11(2):532559

Metz T (2011b) An African theory of dignity and a relational conception of poverty. In: De Gruchy J (ed) The humanist imperative in South Africa. African Sun Media, Stellenbosch, pp 233-241 
Metz T (2012a) Developing African political philosophy: moral-theoretic strategies. Philos Afr 14(1):61-83

Metz T (2012b) An African theory of moral status. Ethical Theory Moral Pract 15(3):387-402

Metz T (2014a) Just the beginning for ubuntu. S Afr J Philos 33(1):65-72

Metz T (2014b) African values, human rights and group rights. In: Onazi O (ed) African legal theory and contemporary problems. Springer, Dordrecht, pp 131-151

Metz T (2015a) African ethics and journalism ethics: news and opinion in light of ubuntu. J Media Ethics 30(2): $74-90$

Metz T (2015b) An African egalitarianism: bringing community to bear on equality. In: Hull G (ed) The equal society: essays on equality in theory and practice. Rowman \& Littlefield, Lanham, MD, pp 185-208

Metz T (2017) The ethics and politics of the brain drain: a communal alternative to liberal perspectives. S Afr J Philos 36(1):101-114

Metz T, Miller SC (2016) Relational ethics. In: LaFollette H (ed) The international encyclopedia of ethics. Blackwell Publishing Ltd, Malden MA, pp 1-10

Mokgoro Y (1998) Ubuntu and the law in South Africa. Potchefstroom Electronic Law J 1(1):15-26

Murove MF (2007) The shona ethic of ukama with reference to the immortality of values. Mankind Q 48(2):179189

Nkulu-N'Sengha M (2009) Bumuntu. In: Asante MK, Mazama A (eds) Encyclopedia of African religion. Sage, Los Angeles, pp 142-147

O'Hear A (2004) The open society revisited. In: Catton P, Macdonald G (eds) Karl Popper: critical appraisals. Routledge, New York, pp 189-202

Popper K (1945a) The open society and its enemies, volume 1: the spell of Plato, 1st edn. George Routledge \& Son Ltd, London

Popper K (1945b) The open society and its enemies, volume 2: the high tide of prophecy: Hegel, Marx, and the aftermath, 1st edn. George Routledge \& Son Ltd, London

Popper K (1966) The open society and its enemies, volume 2: the high tide of prophecy: Hegel, Marx, and the aftermath, 5th edn. Routledge and Kegan Paul, London

Popper K (1976a) The open society. In: Ferguson AT (ed) Revolution or reform?: a confrontation. New University Press, Chicago, pp 65-87

Popper K (1976b) Theoretical background II. In: Ferguson AT (ed) Revolution or reform?: a confrontation. New University Press, Chicago, pp 94-100

Popper K (1992) Conjectures and refutations. Routledge, New York. First published in 1962

Popper K (1994a) Immanuel Kant: the philosopher of the enlightenment. In: Popper K (ed) In search of a better world: lectures and essays from thirty years. Bennett L (trans). Routledge, London, pp 126-136

Popper K (1994b) Emancipation through knowledge. In: Popper K (ed) In search of a better world: lectures and essays from thirty years. Bennett L (trans). Routledge, London, pp 137-150 First broadcast in 1961

Popper K (1994c) What does the west believe in? In: Popper K (ed) In search of a better world: lectures and essays from thirty years. Bennett L (trans). Routledge, London, pp 204-222 First published in 1959

Popper K (1999a) On freedom. In: Popper K (ed) All life is problem solving. Camiller P (trans). Routledge, New York, pp 81-92 First published in 1958

Popper K (1999b) On the theory of democracy. In: Popper K (ed) All life is problem solving. Camiller P (trans). Routledge, New York, pp 93-98 First published in 1987

Popper K (2008a) The open society and the democratic state. In: Shearmur J, Turner PN (eds) After The Open Society. Routledge, London, pp. 231-248 First published in 1963

Popper K (2008b) On democracy. In: Shearmur J, Turner PN (eds) After The Open Society. Routledge, London, pp 360-369 First published in 1988

Pralong S (1999) Minima moralia: is there an ethics of the open society? In: Jarvie AI, Pralong S (eds) Popper's Open Society after fifty years. Routledge, New York, pp 127-143

Rawls J (2001) Justice as fairness: a restatement. Harvard University Press, Cambridge MA

Shearmur J (1996) The political thought of Karl Popper. Routledge, London

Sogolo G (1993) Foundations of African philosophy. Ibadan University Press, Ibadan

Tutu D (1999) No future without forgiveness. Random House, New York

Vincent A (2005) Nationalism and the open society. Theoria 52(107):36-64

Wiredu K (2000) Democracy and consensus in African traditional politics: a plea for a non-party polity. Polylog

2. Available online: https://them.polylog.org/2/fwk-en.htm. Accessed 19 May 2020 